\title{
PEMANFAATAN SAMPAH ANORGANIK AGAR BERNILAI EKONOMIS UNTUK PERBAIKAN RESAPAN AIR HUJAN PADA TANAH RAWA DI KECAMATAN AMUNTAI SELATAN KABUPATEN HULU SUNGAI UTARA
}

\author{
Fitria Handayani, Akhmad Gazali, Robiatul adawiyah, \\ Eka Purnamasari, Hendra Cahyadi \\ Fakultas Teknik, Universitas Islam Kalimantan \\ E-mail : fitriauniska@gmail.com
}

\begin{abstract}
ABSTRAK
Permasalahan yang sering terjadi di desa Telaga Sari yang daerahnya merupakan tanah rawa yaitu terjadinya banjir yang semakin tahun semakin besar karena volume daya tampung saluran primer semakin berkurang. Salah satu penyebabnya adalah kebiasaan buruk warga membuang sampah anorganik (sampah yang sukar terurai dalam tanah) ke saluran primer dan rendahnya pengetahuan tentang drainase (resapan air). Ada cara yang perlu dilakukan agar banjir tahunan dapat dicegah yaitu dengan memperbaiki sistem resapan air ke dalam (drainase). Perbaikan drainase dapat dilakukan dengan tidak membuang sampah yang tidak mudah terurai dengan menggunakan kembali (daur ulang) agar bermanfaat, maupun membuat sumur resapan. Pembuatan sumur resapan tidak memungkin karena memerlukan biaya dan proses yang lama sehingga cara yang digunakan adalah pemanfaatan sampah anorganik menjadi barang yang bermanfaat seperti pot, tempat penyimpanan barang, celengan dan lain sebagainya. Diharapkan dengan adanya program pemanfaatan sampah anorganik ini dapat memperbaiki taraf hidup di bidang sosial, ekonomi, dan pangan.
\end{abstract}

Kata Kunci : Tanah rawa, drainase, sampah anorganik, banjir, saluran primer

\section{PENDAHULUAN}

Seluruh daerah di Desa Telaga Sari merupakan tanah rawa. Kondisi tanah pada daerah rawa adalah jenuh air, yaitu seluruh pori-pori tanah terisi oleh air. Air hujan maupun air yang mengalir dipermukaannya tidak akan diserap ke dalam tanah. Permukaan tanah rawa hanya merupakan daerah yang menampung air di atasnya. Air hujan akan segera meninggikan volume air jika daerahnya menyempit dan terkurung.
Dalam sistem drainase, semakin dalam permukaan air tanah maka semakin besar volume tanah yang mampu diresapi air sehingga semakin tanah mampu banyak menampung air. Namun pada daerah tanah rawa muka air tanah sama tingginya dengan permukaan tanah atau bahkan lebih tinggi dari permukaan tanah. Hal ini menyebabkan daerah rawa tidak mampu menmampung air ke dalam tanah.

Seiring berjalannya waktu karena semakin banyaknya warga yang bermukim di Desa Telaga Sari 
menyebabkan masalah drainase yaitu menumpuknya sampah anorganik di saluran primer (tampungan air utama). Sampah anorganik yang terkubur menjadikan permukaan tanah menjadi kedap air sehingga menghalangi air meresap ke dalam tanah. Apabila jumlahnya sangat banyak dan tidak terkendali akan mengurangi volume tampungan air pada nsaluran primer. Jika musim hujan datang dengan curah air yang tinggi maka terjadilah luapan air ke jalan maupun ke dalam rumah berupa banjir besar (volume air sangat tinggi).

Identifikasi masalah di desa Telaga Sari yaitu sering terjadinya banjir yang semakin tahun semakin besar karena volume daya tampung saluran primer semakin berkurang. Salah satu penyebabnya adalah kebiasaan buruk warga membuang sampah anorganik (sampah yang sukar terurai dalam tanah) ke saluran primer dan rendahnya pengetahuan tentang drainase (resapan air).

Ada cara yang perlu dilakukan agar banjir tahunan dapat dicegah yaitu dengan memperbaiki sistem resapan air ke dalam (drainase). Perbaikan drainase dapat dilakukan dengan tidak membuang sampah yang tidak mudah terurai dengan cara menggunakannya kembali (daur ulang) agar bermanfaat, maupun membuat sumur resapan. Pembuatan sumur resapan tidak memungkin karena memerlukan biaya dan proses yang lama sehingga cara yang digunakan adalah pemanfaatan sampah anorganik menjadi barang yang bermanfaat seperti pot, tempat penyimpanan barang, celengan dan lain sebagainya. Diharapkan dengan adanya program pemanfaatan sampah anorganik ini dapat memperbaiki taraf hidup di bidang sosial, ekonomi, dan pangan.

Sasaran utama kegiatan ini adalah warga yang perumahannya berada di tanah lunak, tokoh masyarakat, pemuda dan ulama masyarakat Desa Telaga Sari RT.04 RW.02 Kecamatan Amuntai Selatan Kabupaten Hulu Sungai Utara. Karena mereka dapat memperluas hasil kegiatan pada anggota sasaran lainnya yaitu masyarakat yang rumahnya berada di tanah rawa.

Tujuan dari kegiatan ini adalah : 1) Masyarakat mengerti dan mengetahui tata cara drainase resapan air hujan. 2) Masyarakat memiliki kesadaran yang tinggi menghindari penyebab permasalahan drainase. 3) Masyarakat 
mengetahui manfaat resapan air ke dalam tanah. 4) Masyarakat berusaha mengatasi banjir tahunan. 5) Masyarakat didukung dan diberdayakan dalam program pemanfaatan sampah yang menyumbat resapan air ke dalam tanah agar menambah penghasilan.

\section{METODE PELAKSANAAN KEGIATAN}

Pelaksanaan program sosialisasi berupa penyuluhan "Pemanfaatan Sampah Kaleng agar Bernilai ekonomis Pada Tanah Rawa Di Kecamatan Amuntai Selatan kabupaten Hulu Sungai Utara" akan dilakukan dengan metode ceramah dan tanya jawab.

1. Tahap Persiapan

Tahap persiapan dalam kegiatan pengabdian ini adalah penyusunan pre planning. Persiapan media berupa power point dengan materi penyuluhan mengenai sanitasi komunal. Langkah pertama adalah membuat kontrak, terkait waktu dan tempat penyuluhan dengan ketua Rukun Tetangga dan perangkat kelurahan setempat beserta unsur masyarakat yang terkait.

2. Tahap Pelaksanaan
Kegiatan penyuluhan ini dilakukan dengan mengumpulkan warga dengan koordinasi ketua rukun Tetangga. Materi akan diberikan kepada para peserta berupa modul/makalah dan gambargambar. Diakhir pemberian ceramah peserta dipersilahkan diberi kesempatan untuk melakukan tanya jawab dengan narasumber. Diharapkan dari sini maka para peserta akan mengerti dan dapat memberikan masukan kepada mereka yang akan mengurug lahan dan halaman rumahnya.

HASIL PELAKSANAAN

KEGIATAN

Kegiatan

penyuluhan

"Pemanfaatan Sampah Kaleng agar Bernilai ekonomis Pada Tanah Rawa Di Kecamatan Amuntai Selatan kabupaten Hulu Sungai Utara" dilaksanakan selama satu hari pada hari Minggu, 07 Februari 2021, kemudian praktek mandiri dilanjutkan sehingga tercapai dua bulan. Kegiatan penyuluhan dilakukan dengan cara mengumpulkan warga Desa Telaga Sari Kecamatan 
Amuntai Selatan dan sudah meminta izin kepada ketua RT setempat.

Kegiatan penyuluhan diawali dengan pemberian informasi melalui brosur tentang pemeliharaan sistem drainase pada tanah rawa, cara memanfaatkan sampah anorganik, dan manfaatnya di bidang ekonomi dan sosial, Kemudian dilanjutkan dengan tanya jawab.

Kesuksesan pelaksanaan pengabdian yang telah dilakukan dapat dilihat motivasi warga yang hadir sebanyak 31 orang mengikuti acara serta pencapaian tujuan kegiatan pengabdian yang telah dilaksanakan. Secara umum tujuan kegiatan pengabdian yang telah ditetapkan sebelumnya dapat dikatakan berjalan dengan baik. Penjelasan pencapaian tujuan kegiatan ini yaitu:

1. Pada umumnya peserta penyuluhan telah memahami. Hal ini dapat dilihat dari antusiasme para peserta saat kegiatan diskusi dan tanya jawab mengenai pentingnya tidak membuang sampah anorganik sembarangan.

2. Para peserta telah melaksanakan pemanfaatan sampah kaleng agar bernilai ekonomis seperti dibuat pot bunga untuk apotik hidup maupun bunga plastik, dibuat celengan, maupun souvenir pernikahan.

Pengabdian masyarakat yang telah dilakukan juga memberikan hasil yang cukup bermanfaat bagi semua pihak yang terkait dalam kegiatan tersebut. Berikut diuraiakan beberapa hasil yang telah dicapai, baik oleh peserta pelatihan maupun tim pelaksana.

1. Peserta penyuluhan

a. Peserta penyuluhan memiliki pengetahuan pentingnya pemeliharaan drainase pada tanah rawa sehingga meningkatkan kesadaran memelihara lingkungan untuk mencegah banjir.

b. Peserta penyuluhan mengetahui cara memanfaatkan sampah anorganik.

c. Membangun kreatifitas peserta penyuluhan dalam memanfaatkan sampah anorganik membuka lapangan kerja sehingga sampah tidak terbuang percuma.

\section{Tim Pelaksana}

a. Tim pelaksana mendapatkan pengalaman dalam praktek kegiatan pelatihan dan peningkatan keahlian di bidang 
ekonomi melalui inovasi daur ulang sampah anorganik.

b. Tim pelaksana menjalin hubungan yang saling menguntungkan dengan warga Desa Telaga Sari untuk meningkatkan pengetahuan tentang pemanfaatan sampah kaleng agar bernilai ekonomis pada tanah rawa di kecamatan amuntai selatan kabupaten hulu sungai utara.
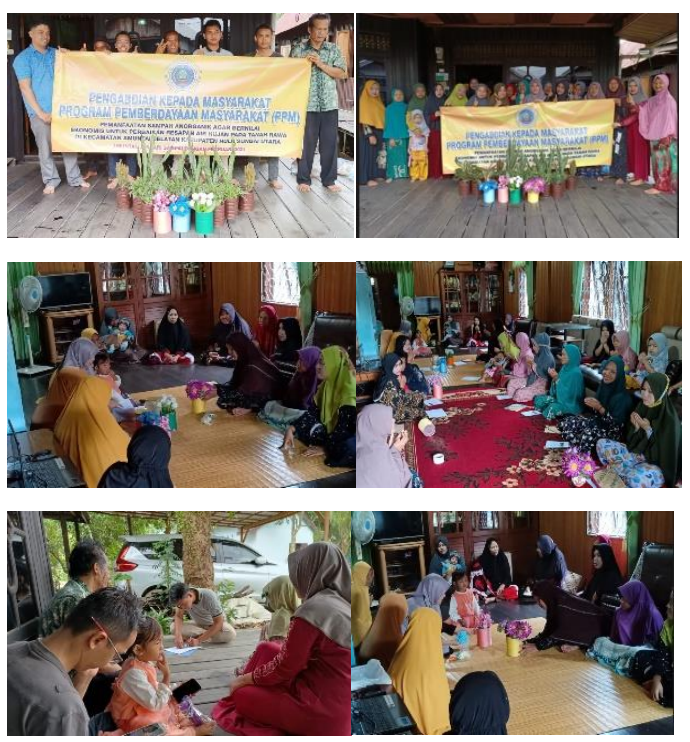

HASIL KARYA MASYARAKAT

\section{DESA TELAGA SARI AMUNTAI}

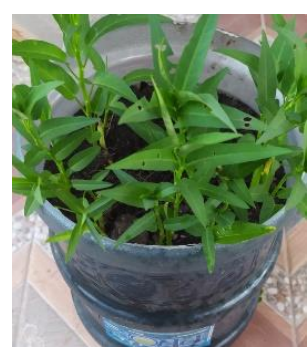

Pemanfaatan bekas Galon bocor untuk menanam kangkung oleh Bapak Barkatullah untuk dikonsumsi sekeluarga

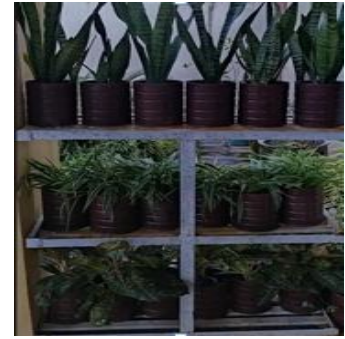

Pemanfaatan bekas kaleng susu untuk menanam tanaman hias oleh Ibu Murdia untuk dijual

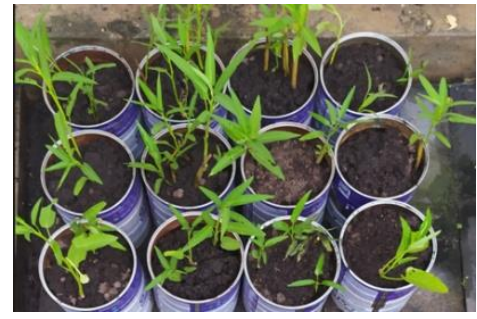

Pemanfaatan bekas kaleng susu untuk menanam pembibitan kangkung oleh Ibu Inayatul untuk dijual

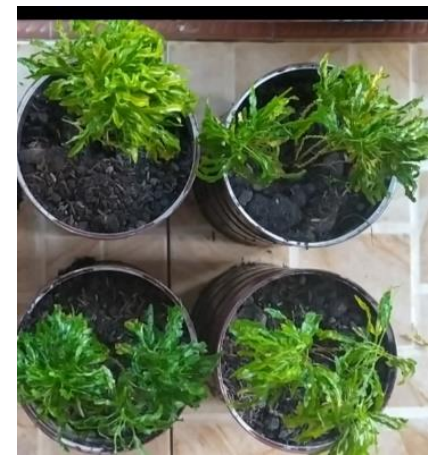

Pemanfaatan bekas kaleng biskuit untuk tanaman hias oleh ibu Istiqamah

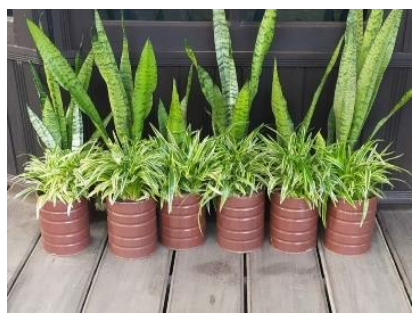

Pemanfaatan bekas kaleng susu untuk menanam tanaman hias oleh pa Syahril untuk dijual 


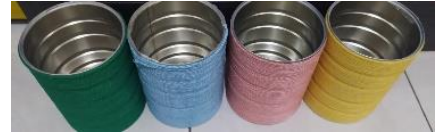

Pemanfaatan bekas kaleng biskuit untuk pot bunga plastik oleh Ibu Norlaila untuk dijual

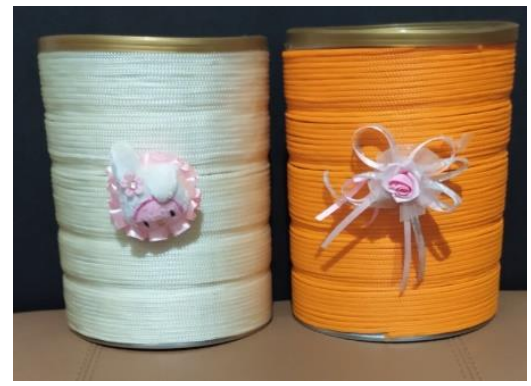

Pemanfaatan bekas kaleng biskuit menjadi celengan oleh Ibu Maria untuk dijual

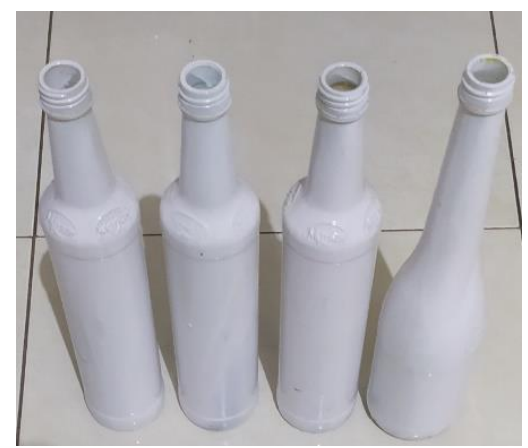

Pemanfaatan botol kaca sirup bekas menjadi pot bunga plastik oleh Ibu Mila

\section{KESIMPULAN}

Dari pelaksanaan kegiatan

Program pemberdayaan masyarakat Pemanfaatan Sampah Kaleng agar Bernilai Ekonomis untuk Perbaikan Resapan Air Hujan pada Tanah Rawa di Kecamatan Amuntai Selatan Kabupaten Hulu Sungai Utara, diperoleh beberapa kesimpulan antara lain sebagai berikut:
1. Bertambahnya pengetahuan warga Desa Telaga Sari dalam menerapkan sistem perbaikan drainase dengan tidak membuang sampah ke saluran primer

2. Tingkat kesadaran warga untuk menghindari banjir besar tahunan menjadi bertambah

3. Warga Desa Telaga Sari yang memanfaatkan sampah anorganik di Desa Telaga Sari menjadi bertambah banyak

4. Warga Desa Telaga Sari mulai memanfaatkan pengolahan sampah yang sangat berdampak di bidang sosial dan ekonomi masyarakat desa.

\section{DAFTAR PUSTAKA}

Anonim. 2013. Materi Bidang Drainase I. Deseminasi dan Sosialisasi Keteknikan Bidang PLP 2013 PU Cipta Karya: Jakarta.

Arifim, M. 2018. Evaluasi Kinerja Sistem Drainase Perkotaan di Wilayah Purwokerto. Jurnal Teknik Sipil-UCY Vol XIII No.1 Februari 2018.

Azizah, S. 2000. Dampak Perkembangan Kota terhadap Peresapan Air Dalam Tanah di Kota Malang Jawa Timur, Surakarta: Forum Geografi UMS.

Fairizi, D. 2015. Analisis dan Evalusi Saluran Drainase pada Kawasan Perumnas Talang 
Kelapa di Subdas Lambidaro Kota Palembang. Jurnal Teknik Sipil dan Lingkungan Vol.3 No.1 Maret 2015.

Handayani, F., dkk. 2020. Alternatif Material Baru Pengolahan Dinding Bangunan Berbahan Abu Batu di kelurahan Telaga Biru Kecamatan Banjarmasin Barat Kota Banjarmasin. Jurnal Al Ikhlas Volume 6, No. 2 (Desember 2020) : 292-297

Iberahim. 2008. Studi Pengembangan Sistem Infrastruktur Pengendalian Air Buangan (Drainase) di Kawasan Permukiman pada Daerah Rawa. Tesis Magister Teknik Sipil. Universitas Lambung Mangkurat.

Kamila, N, dkk. 2016. Perencanaan Sistem Drainase Berwawasan Lingkungan (Ecodrainage) di Kelurahan Jatisari, Kecamatan Mijen, Kota Semarang. Jurnal Teknik Lingkungan ITB Vol. 22 No.2 (2016).

Mariana, dkk. 2018. Penerapan Teknologi Pembuatan
Trikompos di Desa Sungai Bokor Kalimantan Selatan. Jurnal Al Ikhlas Volume 4 Nomor 1, Opktober 2018

Ranthy, Nova Eka. 2005. Studi Evaluasi Jaringan Drainase dan Inlet di Kawasan JL Kawi Kelurahan Bareng Kecamatan Kojen Kota Malang. Fakultas Teknik Jurusan pengairan Universitas Brawijaya Malang.

Rusdi HA. 2009. Sistem Tata Kota yang Baik Menghadapi Bahaya Banjir. Seminar Tatakota: Pemkot Banjarmasin.

Suhardjono. $1984 . \quad$ Drainase. Universitas Brawijaya.

Suripin. 2004. Sistem Drainase Perkotaaan yang Berkelanjutan. Yogyakarta.

Wiwoho, BS. 2008. Analisis Potensi Daerah Resapan Air Hujan di Sub Metro Malang Jawa Timur. Jurnal Geografi FMIPA Universitas Negeri Malang, Tahun 37, Nomor 1, januari 2008. 